\title{
Biologics for Chronic Obstructive Pulmonary Disease: Present and Future
}

\author{
Dave Singh, $M D^{1}$ and Ubaldo Martin, $M D^{2}$
}

${ }^{1}$ University Hospital of South Manchester NHS Foundation Trust, Manchester, UK; ${ }^{2}$ AstraZeneca, Gaithersburg, MD, USA

\section{ABSTRACT}

An unmet need exists for effective treatments for patients with chronic obstructive pulmonary disease (COPD) who continue to experience exacerbations despite receiving standard-of-care treatments. Current advances for COPD are based on an evolving understanding of the molecular mechanisms of increased airway inflammation in stable-state COPD and during acute exacerbations. This review examines the current understanding of the underlying pathophysiology of COPD, discusses clinical trials of novel biologic treatments for COPD, and provides an overview of potential new targets for development of innovative therapies and biomarkers that may be used to identify appropriate patients for these novel treatments. The most promising biologic treatments at an advanced stage of development for COPD are agents targeting eosinophilia, either indirectly through anti-interleukin-5 (IL-5) or directly though anti-IL-5R $\alpha$ (IL-5 receptor alpha) mechanisms. Targeting proteins involved in response to viral infection, such as IL-33, offers further potential for future advances in the development of biologics for COPD. (BRN Rev. 2018;4:34-52) Corresponding author: Ubaldo Martin, Ubaldo.Martin@astrazeneca.com

Key words: Biologic therapy. Biomarkers. Chronic obstructive pulmonary disease. Inflammation. 


\section{INTRODUCTION}

The defining characteristics of chronic obstructive pulmonary disease (COPD) are peripheral airway inflammation and destruction of the lung parenchyma (emphysema), leading to airflow limitation ${ }^{1}$. However, the concept of precisely what constitutes COPD is evolving based on our increased understanding of its pathophysiology and clinical characteristics, which can vary in presence and severity between patients ${ }^{2}$. It has become increasingly clear that COPD is a complex (having several components with non-linear dynamic interactions) and heterogeneous (not all these components are present in all patients or at all time points) condition $^{3}$; and with asthma, COPD is perhaps part of a continuum of different diseases that may share biological mechanisms ${ }^{4}$. Although existing therapies for COPD can improve symptoms and prevent exacerbations, an unmet need exists for effective treatments for patients who continue to experience exacerbations despite receiving current standard-ofcare treatments 5 .

An increased understanding of the underlying pathophysiology of severe asthma has led to treatment advances, including the introduction of novel biologic therapies for the treatment of severe asthma with eosinophilic airway inflammation ${ }^{5}$. Similarly, current advances in treatment for COPD are based on an evolving understanding of the molecular mechanisms of increased airway inflammation in both stable state COPD and during acute exacerbations. However, in addition to disease characteristics that vary between individual patients ${ }^{6,7}$, treatment for COPD is further complicated by the substantial comorbidity burden of this patient population. More than $90 \%$ of patients with COPD report having one or more comorbidities, and approximately $50 \%$ report having four or more ${ }^{8}$. Common comorbidities include hypertension and other cardiac diseases, metabolism disorders, diabetes mellitus, osteoporosis, muscle wasting, cancer, and depression. These comorbidities can directly influence each other. For example, there is evidence that inflammation associated with COPD increases the risk of developing heart disease and lung cancer ${ }^{8}$. Therefore, the management of patients with COPD requires an integrated comprehensive care approach ${ }^{9}$. A comprehensive review of all aspects of COPD management is not the purpose of this review. Here, we focus on the current understanding of the underlying pathophysiology of COPD and provide an overview of clinical trials of novel biologic treatments for COPD. We also review potential new targets for the development of innovative therapies and biomarkers that may be used to identify appropriate patients for these novel treatments.

\section{CHARACTERISTICS OF COPD INFLAMMATION}

COPD is caused by cigarette smoking and inhalation of other noxious particles, such as biomass fuel and chemical fumes ${ }^{10}$. Repeated airway exposure to toxic particles may result in progressive airflow limitation ${ }^{11}$. Observed pathological processes include remodelling and narrowing of small airways and destruction of the lung parenchyma ${ }^{11}$. These processes are most likely related to a chronic inflammatory response to toxic particles in the distal lung, comprising elements of the innate and adaptive immune systems (Fig. 1) ${ }^{11,12}$. An increased burden of oxidants in the lungs, caused 


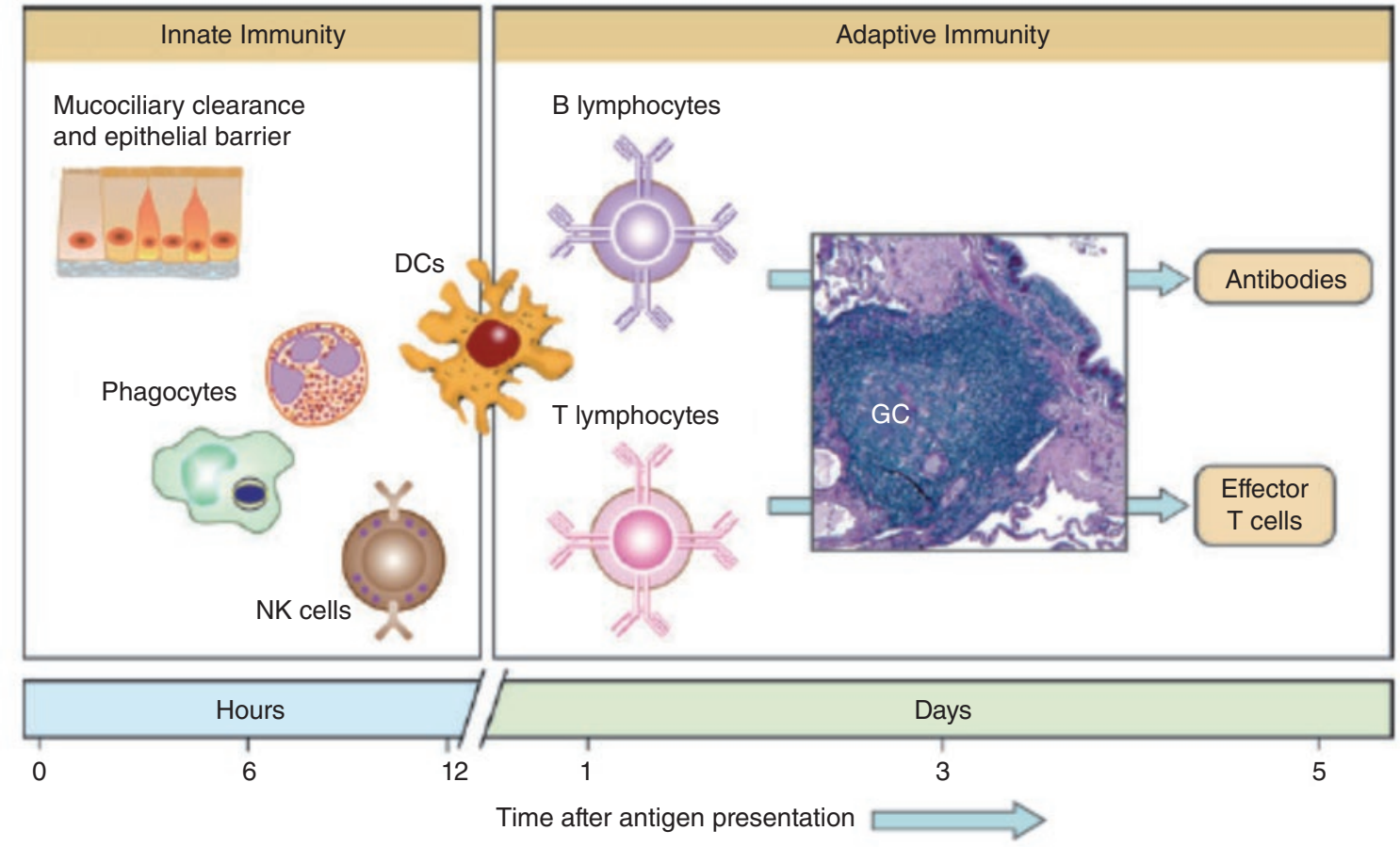

Figure 1. Summary of features of the innate and adaptive immune systems involved in COPD (reproduced with permission from Hogg HC et al. ${ }^{12}$. Annual Review of Pathology: Mechanisms of Disease, Volume 4 (C) 2009 by Annual Reviews, http://www.annualreviews.org).

COPD: chronic obstructive pulmonary disease; DC: dendritic cells; NK: natural killer.

by the release of reactive oxygen species from inflammatory cells in response to inhaled toxic particles, also likely contributes to the development of $\mathrm{COPD}^{13}$.

The innate inflammatory immune system provides the primary protection for the lower respiratory system against inhaled toxic particles. Elements of the innate immune system include mucociliary clearance, tight junctions, circulating receptor molecules, and phagocytic cells ${ }^{12,14}$. A key physical change induced by the toxic particles in cigarette smoke is impaired elimination of pathogens caused by the shortening of cilia, which reduces the mobility of mucus produced by goblet cells ${ }^{15}$. Smoking also causes hyperplasia of mucus-producing goblet cells, and metaplasia of basal cells and squamous epithelial cells $s^{14,15}$. Cigarette smoke is associated with the loss of airway epithelial tight junctions, which normally form an impermeable barrier protecting the respiratory tract from pathogens or harmful particles $^{8,11,12,15}$. The number of neutrophils and macrophages in the lower airways is also increased for patients with $\mathrm{COPD}^{7}$, and the phagocytosis of apoptotic cells by macrophages is impaired ${ }^{14}$.

Amplified innate immunity can alter the adaptive immune response through several mechanisms; for example, innate immune cytokines 
TABLE 1. Immune Cells and Their Role in COPD Inflammation

\begin{tabular}{|c|c|c|c|}
\hline Immune cell & $\begin{array}{l}\text { Innate } \\
\text { or adaptive }\end{array}$ & Observed presence in COPD & $\begin{array}{l}\text { Role(s) associated with COPD disease } \\
\text { characteristics and lung inflammation }\end{array}$ \\
\hline Macrophage & Innate & $\begin{array}{l}\text { Number increased in the lungs of patients with } \\
\text { COPD }\end{array}$ & $\begin{array}{l}\text { Promotes secretion of proinflammatory cytokines } \\
\text { (e.g., TNF, LTB4, IL-8) } \\
\text { Airway macrophages have impaired ability for phagocy- } \\
\text { tosis of apoptotic cells, resulting in decreased } \\
\text { clearance and persistent antigenic stimuli and } \\
\text { inflammation }{ }^{14}\end{array}$ \\
\hline Neutrophil & Innate & $\begin{array}{l}\text { Found in large numbers in the sputum and BAL } \\
\text { fluid of patients with COPD } \\
\text { Neutrophil counts in induced sputum consis- } \\
\text { tently correlate with severity of airflow } \\
\text { obstruction }^{19}\end{array}$ & Produces proteases and reactive oxygen species ${ }^{14}$ \\
\hline Eosinophil & Innate & $\begin{array}{l}\text { Elevated concentrations ( }>3 \% \text { ) found in sputum } \\
\text { of a subset of patients with COPD } \\
\text { Tissue biopsies taken during acute exacerba- } \\
\text { tions show a } 30 \text {-fold increase in eosinophil } \\
\text { concentrations compared with stable COPD } \\
\text { Numbers are increased in sputum during } \\
\text { exacerbations and eosinophilia is associated } \\
\text { with increased risk of exacerbations }{ }^{36,66}\end{array}$ & $\begin{array}{l}\text { Release ECP and EPO, which are toxic to bronchial } \\
\text { epithelial cells, and cytokines, which promote } \\
\text { inflammation }^{19}\end{array}$ \\
\hline CD8+ T cell & Adaptive & $\begin{array}{l}\text { Increased in the airways and parenchyma of } \\
\text { patients with COPD, numbers correlate with } \\
\text { the severity of airway obstruction }{ }^{14,19}\end{array}$ & $\begin{array}{l}\text { Induces apoptosis and necrosis of airway epithelial and } \\
\text { endothelial cells, via release of perforin, granzyme } \\
\text { and TNF }{ }^{14}\end{array}$ \\
\hline CD4+ T cell & Adaptive & $\begin{array}{l}\text { Found in large numbers in the airways and lung } \\
\text { parenchyma in patients with COPD }\end{array}$ & $\begin{array}{l}\text { Mediates, via } T_{1} \text { response, the chemotaxis of innate } \\
\text { (macrophages, neutrophils, and eosinophils) and } \\
\text { adaptive cells ( } T \text { and } B \text { cells) }{ }^{14}\end{array}$ \\
\hline NK lymphocytes & Adaptive & $\begin{array}{l}\text { Functionality is observed to be diminished for } \\
\text { patients with COPD }\end{array}$ & $\begin{array}{l}\text { Diminished functionality results in greater risk of viral } \\
\text { infection and associated exacerbations }{ }^{15}\end{array}$ \\
\hline
\end{tabular}

BAL: bronchoalveolar lavage; COPD: chronic obstructive pulmonary disease; ECP: eosinophil cationic protein; EPO: eosinophil peroxidase; IL: interleukin; LTB4: leukotriene B4; NK: natural killer; $\mathrm{Th}_{1}$ : Type 1 helper cell; TNF: tumour necrosis factor.

can influence the development of certain lymphocyte subsets, triggering cell- and antibodymediated chronic inflammation, which are elements of the adaptive immune system (Table 1 , Fig. 2$)^{11}$.

The activation of the adaptive immune response in COPD is evident by the increased number of CD8+ cells in COPD lung tissue and an increased number of lymphoid follicles ${ }^{16}$, which are more frequent with increasing disease severity ${ }^{12,17}$. Dendritic cells form a key link between the innate and adaptive immune response by presenting antigens to uncommitted $\mathrm{T}$ cells, leading to the expansion of $\mathrm{B}$ cells and the production of antibodies against the presented antigen ${ }^{12}$. However, the nature of the antigens that drive the immune response in COPD is not well characterized. Autoimmune mechanisms and antigens from infectious and noninfectious particles could all possibly be involved $^{12}$. Results of studies reporting the presence of autoantibodies in patients with COPD suggest that carbonyl-modified proteins produced by oxidative stress could promote antibody production, providing a link between oxidative stress and the autoimmune response in $\mathrm{COPD}^{14}$. 


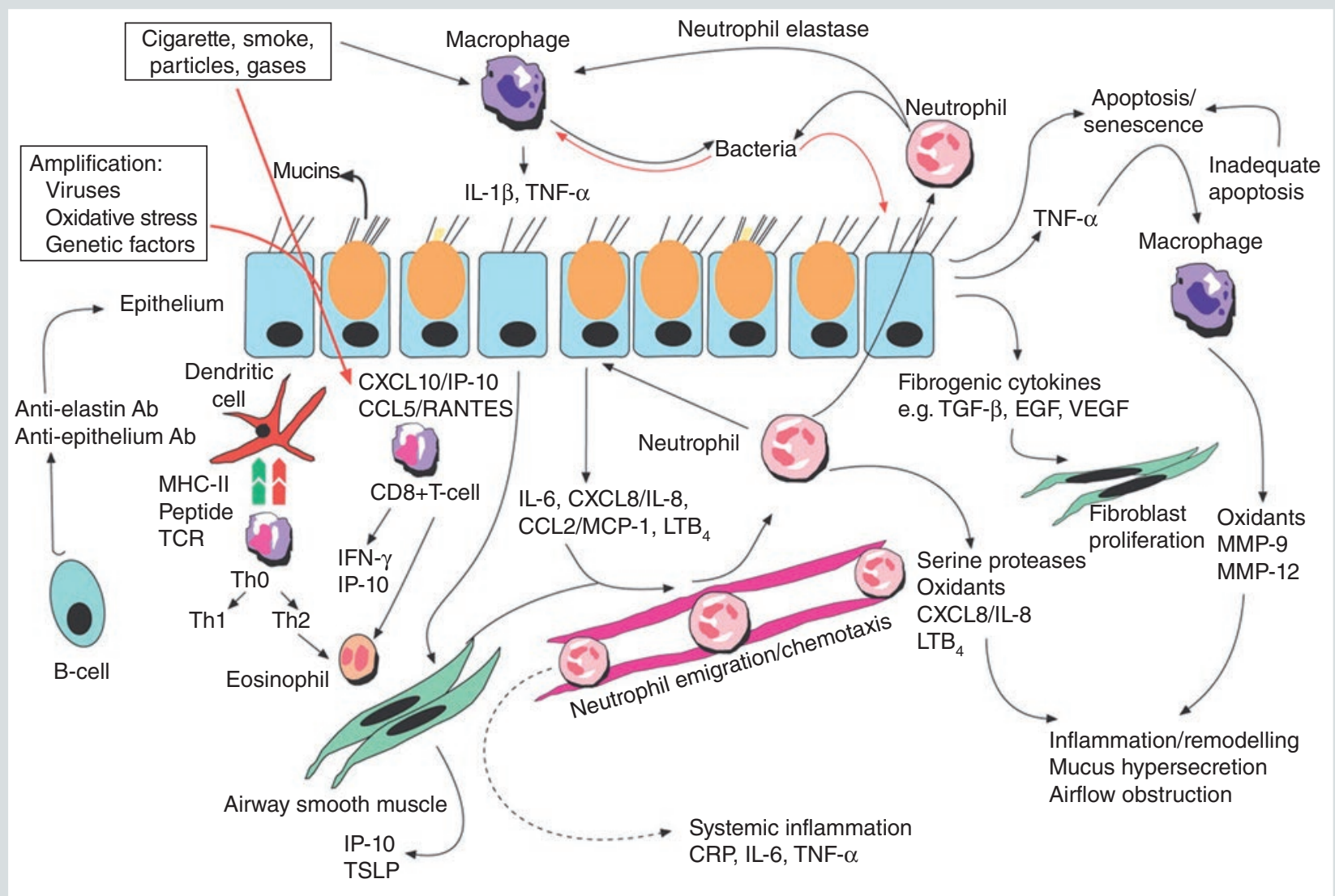

FIGURE 2. Summary of interactions linking chronic cigarette exposure to chronic inflammation in COPD (reproduced with permission from Chung KF et al.27. ERS (C): European Respiratory Journal Jun 2008;31(6):1334-56; DOI: 10.1183/09031936.00018908).

Ab: antibody; B cell: B lymphocyte; CCL: CC chemokine ligand; CRP: C-reactive protein; CXCL, CXC: chemokine ligand; EGF: epidermal growth factor; IL: interleukin; IP: interferon (IFN)-c-inducible protein; LT: leukotriene; MCP: monocyte chemotactic protein; MHC: major histocompatibility complex; MMP: matrix metalloproteinase; TCR, T-cell receptor; Th, T-helper cell; TNF: tumour necrosis factor; TGF: transforming growth factor; TSLP: thymic stromal lymphopoietin; VEGF: vascular endothelial growth factor.

Increased numbers of macrophages, neutrophils, $\mathrm{T}$ and $\mathrm{B}$ lymphocytes, and dendritic cells are observed in the lower airways of patients with $\mathrm{COPD}^{7,8,14}$. However, the predominant inflammatory cell type varies with disease severity, with increased numbers of neutrophils and $\mathrm{B}$ lymphocytes present in more severe $\operatorname{cases}^{11,12,18}$. Furthermore, although eosinophilic inflammation, which is predominantly driven by T-helper 2 cytokine-producing cells, is more often associated with asthma, sputum evaluation identified that a subset of patients with COPD also have eosinophilic inflammation ${ }^{19}$.

\section{COPD EXACERBATIONS}

COPD exacerbations are characterized by increased airway inflammation, increased mucus production, and marked gas trapping, and they can significantly accelerate lung function 
decline of patients with $\mathrm{COPD}^{20}$. Triggers for COPD exacerbations include bacterial or viral infections and exposure to environmental pollutants, but the underlying mechanisms have yet to be fully characterized ${ }^{21}$. The treatment goals for COPD exacerbations are minimizing the impact of the current exacerbation and reducing subsequent exacerbation risk $^{20}$.

Airway exposure to viruses, bacteria, and air pollutants is associated with a risk of COPD exacerbations because these irritants can cause an acute inflammatory response in the airway, which is already in a chronic inflammatory state ${ }^{11,20}$. The elements associated with this acute inflammatory response offer potential targets for therapeutic intervention.

Sputum neutrophil, lymphocyte, and eosinophil counts increase during COPD exacerbations, accompanied by an increase in sputum concentrations of leukotriene B4 and interleukin-8 (IL-8) ${ }^{22}$. A cluster analysis has categorized four biologic exacerbation clusters based on sputum measurements: bacterial-predominant, eosinophil-predominant, viral-predominant, and pauci-inflammatory (limited changes in inflammatory profile) ${ }^{23}$. In this analysis, bacterial- and eosinophil-associated exacerbations rarely coexisted, suggesting fundamental differences in the immunopathogenesis of these exacerbations. Furthermore, for patients with repeated exacerbations, bacterial- or sputum eosinophil-predominant exacerbations could be predicted from the nature of stable disease, suggesting that they are caused by disease instability, whereas viral exacerbations were more likely to be caused by a new pathogen ${ }^{23}$. Other studies have found that an increase in sputum neutrophil count is associated with severe COPD exacerbations initiated by either bacteria or viruses, although an increase in sputum eosinophil count is associated only with virus-induced exacerbations ${ }^{24}$.

Increased CD8+ T lymphocytes with a reduction in the ratio of interferon- $\gamma$ - to IL-4-expressing CD8+ T lymphocytes is also observed during COPD exacerbations, indicating a possible switch toward a type 2-like immunophenotype that could in turn initiate eosinophil recruitment ${ }^{25}$. A greater sputum concentration of eosinophils is associated with a greater risk of exacerbations for patients with $\mathrm{COPD}^{23,26}$.

\section{TARGETS FOR COPD PHARMACOTHERAPY}

\section{Neutrophilic inflammation}

Neutrophils are increased in stable state COPD and increase further in some COPD exacerbations, particularly those induced by bacteria ${ }^{11,22,24}$. Molecules associated with neutrophilic inflammation in COPD that could potentially serve as biomarkers of neutrophilic disease, as well as potential therapeutic targets, include IL-1, IL-6, IL-8, IL-17, IL-23, CXC chemokine receptor 2 (CXCR2), tumour necrosis factor (TNF), granulocyte-macrophage colony-stimulating factor (GM-CSF), and proline-glycine-proline (PGP) (Table 2) $)^{19,27-31}$.

\section{Eosinophilic inflammation}

Although COPD has traditionally been viewed as a neutrophil-driven disease, a subgroup 
TABLE 2. Key cytokines and inflammatory markers associated with COPD

\begin{tabular}{|c|c|c|}
\hline Cytokine/marker & $\begin{array}{l}\text { Pharmacotherapy target(s) } \\
\text { associated with }\end{array}$ & Observed presence/role in COPD \\
\hline IL-1 & Neutrophilic inflammation & $\begin{array}{l}\text { Increased concentrations of IL-1 } \beta \text { reported in serum, sputum and BAL of patients with } \\
\text { COPD }^{28} \\
\text { Amplifies inflammation }{ }^{16}\end{array}$ \\
\hline IL-3 & Eosinophilic inflammation & Key cytokine for basophil survival ${ }^{67}$, also promotes maturation of eosinophils ${ }^{5}$ \\
\hline IL-5/IL-5R $\alpha$ & Eosinophilic inflammation & $\begin{array}{l}\text { Sputum concentrations of IL- } 5 \text { correlate with the degree of eosinophilia and response to } \\
\text { glucocorticoids for patients with stable COPD } \\
\text { Soluble IL-5R } \alpha \text { is increased during virus-induced COPD exacerbations }{ }^{28}\end{array}$ \\
\hline IL-6 & Neutrophilic inflammation & $\begin{array}{l}\text { Plasma and sputum concentrations are increased in patients with stable COPD compared } \\
\text { with controls } \\
\text { May contribute to the pathogenesis of the autoimmune response in the lungs of patients } \\
\text { with severe stable COPD } \\
\text { Amplifies inflammation }{ }^{16}\end{array}$ \\
\hline IL-8 & Neutrophilic inflammation & $\begin{array}{l}\text { Chemotactic for neutrophils and monocytes }{ }^{16} \\
\text { Concentrations increased in sputum and BAL of patients with COPD }\end{array}$ \\
\hline IL-13 & $\begin{array}{l}\text { Eosinophilic inflammation } \\
\text { Lung destruction - emphysema }\end{array}$ & $\begin{array}{l}\text { Driver of type } 2 \text { inflammation produced by } \mathrm{Th}_{2} \text { cells and ILC2 } \\
\text { Mediates mucus hypersecretion, subepithelial fibrosis, and airway hyperresponsiveness } \\
{ }^{5} \\
\text { Induces chemokines that results in eosinophil recruitment and retention in inflamed airway } \\
\text { tissue }^{5}\end{array}$ \\
\hline $\begin{array}{l}\text { IL-17A (alternative } \\
\text { name IL-17) }\end{array}$ & $\begin{array}{l}\text { Neutrophilic inflammation } \\
\text { Bacterial colonization - innate } \\
\text { immune response }\end{array}$ & $\begin{array}{l}\text { Induces the production of mucus in goblet cells }{ }^{15} \\
\text { Promotes activation of bronchial fibroblasts, epithelial cells, smooth muscle cells, that } \\
\text { produce other proinflammatory cytokines that subsequently cause the recruitment of } \\
\text { neutrophils and their infiltration into tissues }{ }^{15} \\
\text { Promotes inflammation by coordinating granulopoiesis and neutrophil mobilization }{ }^{15} \\
\text { Induces the expression of IL-6, TNF, GM-CSF, CXCL1, CXCL8 in epithelial, vascular } \\
\text { fibroblast, neutrophil and eosinophil cells }{ }^{15}\end{array}$ \\
\hline IL-18 & Lung destruction - emphysema & $\begin{array}{l}\text { Pro-inflammatory cytokine }{ }^{16} \\
\text { Increased concentrations in the plasma and sputum of patients with COPD } \\
\text { Contributes to vascular destruction via IL-18-mediated alveolar endothelial apoptosis }{ }^{24}\end{array}$ \\
\hline IL-22 & $\begin{array}{l}\text { Bacterial colonization - innate } \\
\text { immune response }\end{array}$ & $\begin{array}{l}\text { Induces expression of G-CSF }{ }^{15} \\
\text { Maintains the integrity of the epithelium by limiting cellular apoptosis and favouring } \\
\text { regeneration processes } \\
\text { Serum and sputum concentrations are significantly increased in the sputum of stable COPD } \\
\text { patients compared with those of nonsmoking controls }{ }^{28}\end{array}$ \\
\hline IL-23 & $\begin{array}{l}\text { Neutrophilic inflammation } \\
\text { Bacterial colonization - innate } \\
\text { immune response }\end{array}$ & $\begin{array}{l}\text { Linked to autoimmune inflammation }{ }^{68} \\
\text { Induces elastase-induced airway inflammation and emphysematous changes in the lung } \\
{ }^{68}\end{array}$ \\
\hline IL-25 & Eosinophilic inflammation & $\begin{array}{l}\text { Released by airway epithelial cells in response to toxic particles }{ }^{5} \\
\text { Induces eosinophilic inflammation via both ILC2 and } \mathrm{Th}_{2} \text { pathway }^{5}\end{array}$ \\
\hline IL-33 & Eosinophilic inflammation & $\begin{array}{l}\text { Upregulated by cigarette smoke and released in response to viral infection }{ }^{65} \\
\text { Drives Th cell-like inflammatory response to virus infection and potentially plays a critical } \\
\text { role in pathogen-induced exacerbations of COPD }\end{array}$ \\
\hline CXCR2 & Neutrophilic inflammation & Chemokine receptor found on alveolar macrophages, Th $_{1}$ cells, and neutrophils ${ }^{11}$ \\
\hline GM-CSF & $\begin{array}{l}\text { Neutrophilic inflammation } \\
\text { Eosinophilic inflammation }\end{array}$ & $\begin{array}{l}\text { Maintains neutrophilic inflammation }{ }^{16} \\
\text { Involved in induction of eosinophil inflammation and prolonging eosinophil survival in tissues }{ }^{19} \text {; } \\
\text { shares a common receptor with the beta chain for IL-5 receptor and IL-3 receptor }{ }^{69}\end{array}$ \\
\hline HNE & $\begin{array}{l}\text { Neutrophilic inflammation } \\
\text { Lung destruction - emphysema }\end{array}$ & Has elastolytic and pro-inflammatory effects and increases mucus secretion ${ }^{16}$ \\
\hline
\end{tabular}


TABLE 2. Key cytokines and inflammatory markers associated with COPD (Continued)

\begin{tabular}{|c|c|c|}
\hline Gytokine/marker & $\begin{array}{l}\text { Pharmacotherapy target(s) } \\
\text { associated with }\end{array}$ & Observed presence/role in COPD \\
\hline MMP9 & Lung destruction - emphysema & $\begin{array}{l}\text { Has elastolytic and pro-inflammatory effects }{ }^{16} \\
\text { For patients with COPD, release is increased from alveolar macrophages, and increased } \\
\text { expression is observed in lung parenchyma, sputum, and BAL }{ }^{16}\end{array}$ \\
\hline PGP & Neutrophilic inflammation & $\begin{array}{l}\text { Stimulates CXC chemokine receptors CXCR } 1 / 2 \text {, which are associated with IL-8, and potentially } \\
\text { perpetuates neutrophilic inflammation }{ }^{31}\end{array}$ \\
\hline RAGE & Lung destruction - emphysema & $\begin{array}{l}\text { RAGE ligands are increased in patients with COPD and correlate with disease airflow } \\
\text { limitation }{ }^{43} \\
\text { Plasma concentrations of soluble-RAGE are lower in patients with COPD compared with } \\
\text { healthy controls and asthma patients, and concentrations are associated with the } \\
\text { presence of emphysema progression }{ }^{43}\end{array}$ \\
\hline TGF $\beta$ & Lung destruction - emphysema & $\begin{array}{l}\text { Stimulates fibrosis and involved in regulatory T cell function }{ }^{16} \\
\text { Increased expression in lung and bronchial biopsy samples of patients with COPD }\end{array}$ \\
\hline TNF & Neutrophilic inflammation & $\begin{array}{l}\text { Amplifies inflammation }{ }^{16} \\
\text { Concentrations increased in the sputum and serum of patients with COPD }\end{array}$ \\
\hline TSLP & Eosinophilic inflammation & $\begin{array}{l}\text { Expression increased in airway smooth-muscle cells after exposure to cigarette smoke; } \\
\text { acts as a mediator between airway smooth-muscle and mast cells }{ }^{28} \\
\text { Implicated in the induction of glucocorticoid resistance in Th cells during airway inflamma- } \\
\text { tion by controlling the phosphorylation of STAT }{ }^{28}\end{array}$ \\
\hline $\mathrm{NF}-\kappa \mathrm{B}$ & $\begin{array}{l}\text { Bacterial colonization - innate } \\
\text { immune response }\end{array}$ & $\begin{array}{l}\text { Increases the activity of inflammatory genes and inhibits the activity of endogenous } \\
\text { antiproteases }{ }^{16} \\
\text { Activated in macrophages and epithelial cells of patients with COPD }{ }^{16}\end{array}$ \\
\hline
\end{tabular}

BAL: bronchoalveolar lavage; COPD: chronic obstructive pulmonary disease; CXCR2: CXC chemokine receptor 2; GM-CSF: granulocyte macrophage colony-stimulating factor; HNE: human neutrophil elastase; IL: interleukin; IL-5R $\alpha$, IL-5: receptor alpha; ILC2, type 2 innate lymphoid cells; LTB4: leukotriene B4; MMP9: matrix metalloproteinase 9; NF-кB: nuclear factor kappa B; NK: natural killer; PGP: proline-glycine-proline; RAGE: receptor for advanced glycation end products; STAT5: signal transducer and activator of transcription 5; TGFB: transforming growth factor beta; TNF: tumour necrosis factor; TSLP: thymic stromal lymphopoietin.

of patients with COPD have increased lung and blood eosinophils ${ }^{32,33}$, which is associated with lung tissue remodelling and increased expression of IL-519,27,28. Eosinophils are also increased in certain subtypes of COPD exacerbations $^{19,33}$, and minimizing eosinophilic airway inflammation for patients with COPD was shown to reduce the rate of severe exacerbations by $62 \%{ }^{34}$. Elevated blood eosinophils are associated with a $>3$-fold increase in readmission rate for patients with severe $\mathrm{COPD}^{35,36}$.

As previously stated, in COPD, both the adaptive and innate immune response may lead to eosinophilic inflammation. The cytokines
IL-33, IL-25, and thymic stromal lymphopoietin are produced by epithelial cells that have been exposed to pollutants. In turn, these cytokines initiate an adaptive immune response via dendritic cells that stimulate naïve $T$ cells to differentiate into $\mathrm{Th}_{2}$ cells, which produce IL-5, IL-13, and IL-145. An innate immune response potentially occurs via stimulation of type 2 innate lymphoid cells, which also produce large quantities of type 2 cytokines, such as IL-5 and IL-13, but not IL-4 ${ }^{5}$. Targeting eosinophilic inflammation is a promising strategy for reducing exacerbation risk for patients with COPD. Molecular targets for the reduction of eosinophils include IL-5/IL-5 receptor alpha (IL-5R $\alpha)$, IL-13/IL-4 receptor 
alpha (IL-4R $\alpha$ ), chemoattractant receptor-homologous molecules, IL-3, IL-25, IL-33, GM-CSF, and

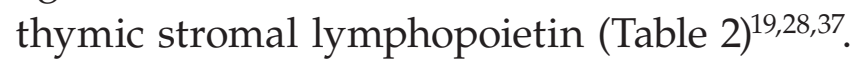

\section{Bacterial colonization and the innate immune response}

Some studies found that the lung microbiome differs for patients with COPD compared with controls, possibly a result of smokinginduced microbiota changes ${ }^{38}$. Furthermore, there is overgrowth of pathogenic bacteria colonizing the lower airways in some patients with $\mathrm{COPD}^{38}$. An inverse relationship was observed for patients with stable COPD between airway bacterial load and sputum eosinophils, suggesting that bacterial infection influences the inflammatory profile and may contribute to neutrophilia and insensitivity to corticosteroids in many patients with $\mathrm{COPD}^{39}$.

IL-17, IL-22, IL-23, and nuclear factor kappa B $\left(\mathrm{NF}_{\mathrm{K}} \mathrm{B}\right)$ have been identified as being associated with bacterial colonization of the lower airways and offer potential therapeutic targets in the management of COPD (Table 2) $)^{16,28,40}$.

\section{Lung destruction - emphysema}

Destruction of the lung parenchyma is caused by inflammatory cells releasing proteases ${ }^{41}$. These proteases include leukocyte elastase, proteinase 3, matrix metalloproteinases, cysteine proteinases, and plasminogen activators, and they are predominantly produced by macrophages, neutrophils, eosinophils and basophils ${ }^{41}$.

IL-18, IL-13, cysteine protease, elastases, and matrix metalloproteinase 9 have been associated with emphysema in COPD and are potential targets for therapeutic intervention (Table 2) ${ }^{16,27,42}$, receptor for advanced glycation end products (RAGE) and its soluble form have also been identified as a therapeutic target and biomarker, respectively, for emphysema ${ }^{43}$.

Autoimmune responses have also been implicated in COPD-associated emphysema, and identification of specific autoantibodies associated with emphysema offers potential novel therapeutic targets (e.g., anti-glucose-regulated protein 78 and anti-elastin) ${ }^{44}$.

\section{CLINICAL TRIALS OF NOVEL BIOLOGIC THERAPIES IN COPD}

Table 3 summarizes the completed Phase II/III clinical trials with published results that have investigated novel biologic therapies in COPD patients; these studies are discussed in more detail below.

\section{Anti-IL-1}

IL-1 is associated with neutrophilic inflammation in COPD, where it has a role in the amplification of inflammation ${ }^{16}$. Two investigational biologics targeting IL-1 were evaluated for patients with COPD. The human immunoglobulin G (IgG) kappa monoclonal antibody canakinumab binds to IL-1 $\beta$, preventing interaction of IL-1 $\beta$ with IL-1 receptor (IL-1R) ${ }^{45}$. In a Phase I/II interventional study of 147 patients with COPD (NCT00581945), patients were randomized to receive either canakinumab ( $\mathrm{n}=74$; initial intravenous infusion $1 \mathrm{mg} / \mathrm{kg}$, followed by $3 \mathrm{mg} / \mathrm{kg} 2$ weeks later and then $6 \mathrm{mg} / \mathrm{kg}$ every 4 weeks until study 
TABLE 3. Summary of Completed Phase II/III Clinical Trials Investigating Novel Biologic Therapies in COPD

\begin{tabular}{|c|c|c|c|c|c|}
\hline $\begin{array}{l}\text { Drug (patient } \\
\text { population) }\end{array}$ & Drug class & $\begin{array}{l}\text { NCT } \\
\text { number }\end{array}$ & $\begin{array}{l}\text { Phase } \\
\text { (n) }\end{array}$ & $\begin{array}{l}\text { Publication } \\
\text { year }\end{array}$ & Endpoint results \\
\hline ABX-IL8 ${ }^{54}$ & Anti-IL-8 & NCT00035828 & II (119) & 2004 & $\begin{array}{l}\text { Primary. TDI total score differences between ABX-IL8 and } \\
\text { placebo were } 0.8,1.0,0.8 \text {, and } 0.3 \text { at week } 2(\mathrm{p}=0.046) \text { and } \\
\text { months } 1 \text { to } 3 \text {, respectively } \\
\text { Secondary. No statistically significant differences between } \\
\text { groups in health status, lung function, } 6 \mathrm{MWD} \text {, or use of rescue } \\
\text { medication }\end{array}$ \\
\hline Benralizumab ${ }^{53}$ & $\begin{array}{r}\text { Anti-IL-5R } \alpha \\
\text { with ADCC }\end{array}$ & NCT01227278 & IIa (101) & 2014 & $\begin{array}{l}\text { Primary. Annualized rate of acute exacerbations of COPD: } \\
\text { benralizumab } 0.95 \text {, placebo } 0.92 \text { (no significant difference) } \\
\text { Secondary. Significant increase in pre-bronchodilator FEV } \text {, versus } \\
\text { placebo ( } 0.13 \mathrm{~L} \text { versus }-0.06 \mathrm{~L} ; \mathrm{p}=0.014 \text { ); no significant } \\
\text { differences between groups in change from baseline for mean } \\
\text { SGRO-C, CRQ-SAS, BODE scores; no difference in treat- } \\
\text { ment-emergent adverse events between treatment groups }\end{array}$ \\
\hline CNTO $6785^{55}$ & Anti-IL-17A & NCT01966549 & II (187) & 2017 & $\begin{array}{l}\text { Primary. Difference in change from baseline in pre-bronchodilator } \\
\text { percent-predicted FEV }{ }_{1} \text { between CNTO } 6785 \text { and placebo } \\
\text { patients was }-0.49 \% ; p=0.599 \text { ) } \\
\text { Secondary. No statistically significant differences in exacerbation } \\
\text { rate, use of rescue medication, SGRO-C or E-RS }{ }^{\text {TM }} \text { scores were } \\
\text { observed between groups }\end{array}$ \\
\hline Canakinumab ${ }^{45}$ & Anti-IL-1 $\beta$ & NCT00581945 & I/II (147) & 2011 & $\begin{array}{l}\text { Primary. No significant change from baseline in } \mathrm{FEV}_{1} \text {, FVC, SVC or } \\
\text { forced expiratory flow } 25-75 \% \text { for patients receiving canakinum- } \\
\text { ab compared with placebo }\end{array}$ \\
\hline Etanercept ${ }^{60}$ & TNFi & NCT00789997 & II/III (81) & 2012 & $\begin{array}{l}\text { Primary. Absolute change in } \mathrm{FEV}_{1} \text { from baseline to } 14 \text { days was } \\
0.1391 \text { and } 0.1641 \text { for etanercept- and prednisone-treated } \\
\text { patients, respectively }(\mathrm{p}=0.75) \text {; mean between-group treatment } \\
\text { difference was } 0.024 \mathrm{I}(\mathrm{p}=0.75) \text {; mean change in } \mathrm{FEV}_{1} \text { from } \\
\text { baseline was } 15.2 \% \text { and } 20 \% \text { for etanercept and prednisone } \\
\text { groups, respectively } \\
\text { Secondary. No statistically different differences were observed } \\
\text { between treatment groups in change from baseline in } \mathrm{FEV}_{1} \text { at } \\
\text { any time point, treatment failure up to } 90 \text { days, improvements in } \\
\text { TDI or CRO scores }\end{array}$ \\
\hline Infliximab 57 & TNFi & NA & II (14) & 2005 & $\begin{array}{l}\text { Primary. Percentage of sputum neutrophils, change from baseline } \\
\text { to week } 8 \text { of }+0.2 \text { for infliximab and }+0.3 \text { for placebo (not } \\
\text { statistically significantly different) } \\
\text { Secondary. No statistically significant differences between } \\
\text { treatment groups in respiratory symptoms, HROOL, lung } \\
\text { function, safety, or tolerability; nonsignificant trend toward } \\
\text { improvement in 6MWD test with infliximab }\end{array}$ \\
\hline Infliximab ${ }^{58}$ & TNFi & NCT00056264 & III (234) & 2007 & $\begin{array}{l}\text { Primary. Change from baseline at week } 24 \text { in } \mathrm{CRO} \text { total; no } \\
\text { significant change over placebo } \\
\text { Secondary. Pre-bronchodilator FEV }{ }_{1}, 6 \mathrm{MWD}, \mathrm{SF}-36 \text { physical score, } \\
\text { TDI, moderate to severe exacerbation rate; no significant } \\
\text { differences observed between treatment groups }\end{array}$ \\
\hline $\begin{array}{l}\text { MED18986 } \\
\text { (AMG108) }^{46}\end{array}$ & Anti-IL-1 $\alpha$ & NCT01448850 & II (324) & 2017 & $\begin{array}{l}\text { Primary. Annualized rate of moderate/severe acute exacerbations } \\
\text { of COPDa was } 0.71 \text { versus } 0.78 \text { for MED18968 and placebo, } \\
\text { respectively ( } 8 \% \text { reduction associated with MED18968; not } \\
\text { statistically significant) } \\
\text { Secondary. No significant difference between treatments in rate } \\
\text { of severe acute exacerbations; no significant differences } \\
\text { between treatment groups in change from baseline in SGRO-C } \\
\text { total score or symptom domain scores }\end{array}$ \\
\hline
\end{tabular}


TABLE 3. Summary of Completed Phase II/III Clinical Trials Investigating Novel Biologic Therapies in COPD (Continued)

\begin{tabular}{|c|c|c|c|c|c|}
\hline $\begin{array}{l}\text { Drug (patient } \\
\text { population) }\end{array}$ & Drug class & $\begin{array}{l}\text { NCT } \\
\text { number }\end{array}$ & $\begin{array}{l}\text { Phase } \\
\text { (n) }\end{array}$ & $\begin{array}{l}\text { Publication } \\
\text { year }\end{array}$ & Endpoint results \\
\hline Mepolizumab ${ }^{49}$ & Anti-IL-5 & $\begin{array}{l}\text { NCT02105948 } \\
\text { (METREX) }\end{array}$ & III (837) & 2017 & $\begin{array}{l}\text { Primary. Significantly reduced the annual exacerbation rate vs. } \\
\text { placebo for patients with eosinophilic phenotype }{ }^{b}(1.40 \text { versus } \\
1.71 ; n=462 ; p=0.04) \text {; difference was not significant in the } \\
\text { overall population } \\
\text { Secondary. Mepolizumab associated with a significant reduction } \\
\text { in time to first moderate/severe exacerbation in the eosinophilic } \\
\text { population (192 versus } 141 \text { days; } p=0.04) \text {; no statistically } \\
\text { significant differences in any other endpoints between groups }\end{array}$ \\
\hline Mepolizumab 49 & Anti-IL-5 & $\begin{array}{c}\text { NCT02105961 } \\
\text { (METREO) }\end{array}$ & III (674) & & $\begin{array}{l}\text { Primary. Rate ratios for exacerbations were } 0.80(\mathrm{p}=0.07) \text { and } \\
0.86(\mathrm{p}=0.14) \text { versus placebo for } 100-\mathrm{mg} \text { and } 300-\mathrm{mg} \text { dosages of } \\
\text { mepolizumab, respectively } \\
\text { Secondary. No statistical significance in any endpoints versus } \\
\text { placebo in either group }\end{array}$ \\
\hline
\end{tabular}

aWorsening of $\geq 2$ major symptoms or worsening of one major and one minor symptom for $\geq 2$ consecutive days.

bPatients with blood eosinophil counts $\geq 150$ cells/ $\mu \mathrm{L}$ at screening or $\geq 300$ cells/ $\mu \mathrm{L}$ within the previous.

ADCC: antibody-dependent cell-mediated cytotoxicity; BODE: body-mass index, degree of airflow obstruction and dyspnoea, and exercise capacity; CNTO 6785: a fully human IgG1 lambda monoclonal antibody that binds to IL-17A, targeting the IL-17 induced production of pro-inflammatory cytokines; COPD: chronic obstructive pulmonary disease; CRO(-SAS): chronic respiratory questionnaire (self-administered standardized); E-RSTM: exacerbations of chronic pulmonary disease tool-respiratory symptoms; FEV; forced expiratory volume in 1 second; FVC: forced vital capacity; HROOL: health-related quality of life; IL: interleukin; IL-5 receptor alpha; METREO: Mepolizumab vs. Placebo as Add-on Treatment for Frequently Exacerbating COPD Patients Characterized by Eosinophil Level trial; METREX: Mepolizumab vs. Placebo as Add-on Treatment for Frequently Exacerbating COPD Patients trial; NA: not available; NCT: national clinical trial; SGRO-C: St George's respiratory questionnaire for COPD; SF-36: short form 36 health survey; SVC: slow vital capacity; 6MWD: 6-minute walk distance; TDI: Transitional Dyspnoea Index; TNFi: tumour necrosis factor-alpha inhibitor.

completion at 45 weeks) or placebo $(n=73)^{45}$. The primary objective was the impact on pulmonary function compared with placebo. No statistically significant changes from baseline in forced expiratory volume in 1 second $\left(\mathrm{FEV}_{1}\right)$ or other lung function measurements were observed with canakinumab compared with placebo treatment ${ }^{45}$.

\section{MED18968 (AMG108) is a fully human mono-} clonal antibody that selectively binds to IL-1 receptor 1 (IL-1R1) ${ }^{46}$. MED18968 was evaluated for the treatment of patients with symptomatic moderate to severe COPD in a Phase II, multicentre, parallel group, randomized placebo controlled trial (RCT; NCT01448850). COPD patients with a history of $\geq 2$ exacerbations in the previous year were randomized to 600-mg intravenous dose on day 1 (loading dose), followed by 300 mg subcutaneous (two 150-mg injections) every 4 weeks (Q4W) for a total of 14 doses (MED18968, $\mathrm{n}=160$; placebo, $\mathrm{n}=164)^{46}$. The primary endpoint was a reduction in the annualized rate of moderate to severe COPD exacerbations $^{44}$. MED18968 was well-tolerated but had no effect on the rate of moderate or severe exacerbations or health-related quality of life (HRQOL). MED18968 treatment was, however, associated with a statistically significant reduction in blood neutrophil count, serum C-reactive protein (CRP) and fibrinogen concentration, compared with placebo ${ }^{46}$.

\section{Anti-IL-5/IL-5R $\alpha$}

IL-5 is associated with eosinophilic inflammation in COPD, and soluble IL-5R $\alpha$ is elevated during virus-induced COPD exacerbations ${ }^{28}$. Two biologic treatments targeting the IL-5 
ligand, mepolizumab and benralizumab, were investigated for patients with COPD. Mepolizumab is a humanized, IgG $_{1}$, anti-IL-5 monoclonal antibody that binds IL-5 to prevent IL-5-associated signalling ${ }^{47}$. Mepolizumab is approved for the treatment of severe, eosinophilic asthma ${ }^{47,48}$ and was also evaluated for patients with eosinophilic COPD in two key clinical trials that focused on exacerbation prevention.

The Mepolizumab vs. Placebo as Add-on Treatment for Frequently Exacerbating COPD Patients Characterized by Eosinophil Level trial (METREO) Phase III study (NCT02105961) evaluated two dosages of mepolizumab (100 mg and $300 \mathrm{mg}$, every 4 weeks) versus placebo $(n=674)$ for 62 weeks for patients with $\geq 2$ exacerbations or $\geq 1$ severe exacerbations in the previous year and an eosinophilic phenotype ( $\geq 150$ cells $/ \mu \mathrm{L}$ at screening or $\geq 300$ cells $/ \mu \mathrm{L}$ during the previous year). The exacerbation rate ratios in the 100-mg and 300-mg mepolizumab groups compared with placebo were 0.80 and 0.86 , neither reaching statistical significance $(\mathrm{p}=0.07 \text { and } \mathrm{p}=0.14 \text {, respectively })^{49}$. No secondary endpoints in this trial were observed to be significantly different between treatments.

The Mepolizumab vs. Placebo as Add-on Treatment for Frequently Exacerbating COPD Patients trial (METREX) Phase III study (NCT02105948) compared mepolizumab 100 mg every 4 weeks with placebo $(n=837)$ over 52 weeks for patients with COPD who had $\geq 2$ exacerbations or $\geq 1$ severe exacerbations in the previous year. Patients with both eosinophilic $(\geq 150$ cells $/ \mu \mathrm{L}$ at screening or $\geq 300$ cells $/ \mu L$ during the previous year) and noneosinophilic $(<150$ cells $/ \mu \mathrm{L}$ at screening and no evidence of $\geq 300$ cells $/ \mu \mathrm{L}$ in the previous year) phenotypes were included, and results were analysed for those with baseline blood eosinophil counts $\geq 150$ cells $/ \mu \mathrm{L}$ versus $<150$ cells $/ \mu \mathrm{L}$. Mepolizumab reduced the mean annual exacerbation rate for patients with eosinophilia ( $n=462 ; 1.40$ versus 1.71 exacerbations/year; $p=0.04$ ). No significant benefit over placebo was observed in the overall population $^{49}$, and no statistically significant differences were observed between the two groups in patient-reported outcomes.

A prespecified post-hoc meta-analysis of the eosinophilic patient populations $(\geq 300$ cells $/ \mu \mathrm{L}$ at screening or during the previous year) from the combined METREX and METREO trials found that the rate of moderate or severe exacerbations was $23 \%$ lower for patients treated with mepolizumab $100 \mathrm{mg}$ compared with placebo recipients (rate ratio, 0.77$)^{49}$. In both trials, no significant differences in adverse events were observed. Similarly, a meta-analysis evaluating exacerbation rate reduction of glucocorticoids (alone or in addition to antibiotics) or antibiotics alone was conducted. Although the meta-analysis demonstrated greater treatment effects with mepolizumab versus placebo with increasing screening blood eosinophil counts for exacerbations treated with glucocorticoids, these effects were not observed for patients treated with antibiotics ${ }^{49}$. For these patients, the point estimate tended to favour placebo across all eosinophil strata. It is unclear whether this effect relates to the selected patient population and the type of exacerbations patients experienced, or whether it suggests that breakthrough exacerbations during treatment with an anti-IL-5 biologic require systemic steroid treatment.

Benralizumab is a humanized, afucosylated, anti-IL-5R $\alpha$ monoclonal antibody that prevents 
IL-5 signalling by binding to the IL-5R $\alpha$ cell surface receptor and rapidly and directly depletes sputum and blood eosinophils and basophils via enhanced antibody-dependent cell-mediated cytotoxicity ${ }^{50}$. Benralizumab is efficacious for the treatment of patients with severe, eosinophilic asthma ${ }^{51,52}$, and indicated for the add-on maintenance treatment of patients with severe asthma aged 12 years and older and with an eosinophilic phenotype. Benralizumab was evaluated in a Phase IIa, multicentre, randomized, double-blind, placebo-controlled study (52 weeks) of 101 patients with moderate to severe COPD (NCT01227278) ${ }^{53}$. Inclusion criteria included $\geq 1$ moderate or severe exacerbation in the previous year and a sputum eosinophil count $\geq 3 \%$ in the previous year or at screening ${ }^{53}$. Benralizumab treatment $(n=51)$ had no effect on the primary endpoint of exacerbation rates versus placebo $(n=50)$, but was associated with significant improvements in pre-bronchodilator $\mathrm{FEV}_{1}$ compared with placebo $(0.13 \mathrm{~L}$ versus $-0.06 \mathrm{~L}$; $\mathrm{p}=0.014$ ) as early as week 4 . A prespecified subanalysis indicated a $31 \%$ reduction in exacerbations with benralizumab versus placebo treatment for patients with baseline blood eosinophils $\geq 200$ cells $/ \mu L^{53}$. Patients with blood eosinophils $\geq 200$ cells $/ \mu \mathrm{L}$ also exhibited significant improvement in $\operatorname{FEV}_{1}(p=0.035)$, whereas patients with lower eosinophil counts did not ${ }^{53}$. Benralizumab depleted blood and sputum eosinophils by weeks 4 and 8 , respectively ${ }^{53}$.

Two ongoing Phase III studies are evaluating benralizumab for patients with eosinophilic COPD (NCT02138916 and NCT02155660). Although mepolizumab and benralizumab have different mechanisms of action, they seem to share blood eosinophils as a biomarker, as evidenced by a greater magnitude of the effect on exacerbations with increasing blood eosinophil counts. As noted, mepolizumab reduces eosinophils, while benralizumab depletes them. Potential differences in the outcomes of mepolizumab and benralizumab clinical trials may be caused by differences in the pharmacologic characteristics of the drugs or in the respective trial populations ${ }^{49}$.

\section{Anti-IL-8}

IL-8 is associated with neutrophilic inflammation in COPD, where it acts as a chemotactic for neutrophils and monocytes ${ }^{16}$. ABX-IL8 is a fully human monoclonal $\operatorname{IgG}_{2}$ antibody directed against IL-8, thereby potentially targeting neutrophil activation ${ }^{54}$. ABX-IL8 was evaluated in a Phase II RCT versus placebo over a 3-month period for patients with stable COPD aged $>50$ years $(n=119$; NCT00035828). Despite small improvements in the primary endpoint of transitional dyspnoea index (TDI), anti-IL-8 treatment was not associated with significant differences versus placebo in lung function, health status, or 6-minute walking distance $(6 \mathrm{MWD})^{54}$.

\section{Anti-IL-17}

IL-17 is associated with neutrophilic inflammation and bacterial colonization in COPD. It is involved with mucus production and stimulation of other cells to produce proinflammatory cytokines to implement neutrophil recruitment ${ }^{15}$. CNTO 6785 is a fully human $\operatorname{IgG}_{1}$ lambda monoclonal antibody that binds to IL-17A, targeting the IL-17 induced production of pro-inflammatory cytokines ${ }^{55}$. 
CNTO 6785 was evaluated in a Phase II RCT versus placebo for patients with moderate to severe symptomatic COPD at risk for exacerbation (inclusion criteria included $\geq 2$ exacerbations requiring antibiotics and/or systemic corticosteroids in the previous 2 years; $\mathrm{n}=187$; NCT01966549). Treatment consisted of CNTO $67856 \mathrm{mg} / \mathrm{kg}$ or placebo for 12 weeks, and continued up to week 24 . No difference was observed in the primary endpoint (change from baseline in pre-bronchodilator percentpredicted $\mathrm{FEV}_{1}$ versus placebo [p $\left.\left.=0.599\right]\right)^{55}$. No treatment differences were observed for any secondary endpoints, including exacerbation rate and patient-reported outcomes ${ }^{55}$.

\section{TNF antagonists}

TNF is associated with neutrophilic inflammation in COPD, acting to amplify inflammation $^{16}$. An increase in systemic TNF observed in some patients with COPD has also been implicated in skeletal muscle wasting, which occurs in some patients with more severe disease $^{56}$. Evaluations of TNF antagonists for patients with COPD have reported conflicting results. Infliximab, a chimeric monoclonal antibody that binds to soluble and membrane-bound TNF, was evaluated in a Phase II, single-centre, randomized, double-blind, placebo-controlled study ( $\mathrm{n}=22 ; 8$ weeks) for patients with mild to moderate COPD ${ }^{57}$. No statistically significant differences were observed between treatment groups for percentage change of sputum neutrophils from baseline (primary endpoint $p>0.5)$, lung function, concentration of IL-8, or HRQOL ${ }^{52}$. The study investigators suggested that the non-severe COPD patient population could have contributed to this lack of efficacy ${ }^{57}$. A subsequent Phase III, dosage-finding RCT, again in patients with mild to moderate COPD, compared $3 \mathrm{mg} / \mathrm{kg}$ infliximab or $5 \mathrm{mg} / \mathrm{kg}$ infliximab with placebo ( $n=234$; NCT00056264) $)^{58}$. Infliximab failed to demonstrate a benefit over placebo in the chronic respiratory questionnaire (CRQ) total score at week 24 (primary endpoint) at either dosage evaluated or in any of the secondary endpoints evaluated $\left(\mathrm{FEV}_{1}, 6 \mathrm{MWD}\right.$, TDI, and exacerbation rate $)^{58}$.

In a large observational study of 15,771 patients with rheumatoid arthritis and COPD evaluating infliximab and etanercept, etanercept was associated with a reduction in the risk of COPD-related hospitalization (relative risk: 0.49), but no risk reduction was observed with infliximab ${ }^{59}$. A subsequent Phase II/III RCT evaluated etanercept versus oral prednisone for patients with an acute COPD exacerbation presenting to emergency departments $(n=81$; NCT00789997). Patients were randomized to receive prednisone $40 \mathrm{mg}$ orally for 10 days or subcutaneous etanercept $50 \mathrm{mg}$ on days 1 and 7; all patients received antibiotics, an inhaled long-acting $\beta_{2}$-agonist and an inhaled long-acting anticholinergic bronchodilator ${ }^{60}$. No difference was observed in the primary endpoint of change from baseline to Day 14 in $\mathrm{FEV}_{1}(\mathrm{p}=0.75)$. Evaluations at Day 14 or 90 failed to show differences in dyspnoea or CRQ. Treatment during an exacerbation was limited to two doses of etanercept and may have impacted outcomes ${ }^{60}$.

A recent retrospective study evaluated patients with COPD and underlying autoimmune conditions $(n=40,687)$ who had received anti-TNF therapy ${ }^{29}$. TNF-alpha antagonist monotherapy (adalimumab, certolizumab, etanercept, infliximab, or golimumab) had a 
comparable rate of hospitalizations for COPD exacerbations as nonbiologic disease-modifying agents (methotrexate, minocycline, sulfasalazine, hydroxychloroquine, leflunomide, cyclosporine, azathioprine, or gold sodium thiomalate). However, a TNF antagonist and nonbiologic disease-modifying agent in combination was associated with a $32 \%$ reduction in COPD-related hospitalization/emergency department visits compared with nonbiologic disease-modifying agents alone ${ }^{29}$.

In addition to the conflicting efficacy findings reported with anti-TNF therapy for patients with COPD, these trials suggest some potential safety concerns. TNF-antagonist therapy was associated with a statistically nonsignificant increase in clinically diagnosed pneumonia and newly diagnosed malignancies ${ }^{56}$. These malignancies were predominantly of the respiratory tract, suggesting that TNF-antagonist therapy may accelerate the growth of pre-existing cancers in this smoking population at high risk for respiratory cancer.

\section{FUTURE DIRECTIONS}

COPD is a complex condition associated with multiple abnormalities in cell biology. It is recognized that a diverse range of mechanisms are likely to contribute to the individual patient's clinical manifestation of the disease ${ }^{61}$. The heterogeneity between patients in the clinical presentation of COPD underscores that the underlying mechanisms must vary greatly between individuals. An endotype is a subgroup of patients defined by a biologic mechanism $^{2}$. The clinical identification of an endotype requires the development of biomarkers related to the mechanism. Given the heterogeneity and complexity of COPD, the development of biologic treatments for COPD requires a biomarker-driven approach to identify the patients most appropriate for treatment and optimize the benefit versus risk profile ${ }^{7}$. Until now, the development of biologic treatments in COPD have relied excessively on establishing inflammatory parallels between diseases such as rheumatoid arthritis and asthma and COPD, which may have led to failed approaches ${ }^{57,58}$. The paucity of experimental models and precise target validation in a complex entity such as COPD has hampered the advance of biologics in COPD. These aspects are critical to future success.

We recognize that COPD have pronounced systemic effects. Whether these effects are related to a common inflammatory cascade or they are the result of the presence comorbidities is unclear. Irrespective of their origins, systemic manifestations of COPD such as skeletal muscle weakness and atrophy could represent future targets for biologics. The paucity of data regarding a potential inflammatory state, which could be the result of a "spillover" of local inflammation in the lungs or a systemic inflammatory effect affecting multiple organ systems ${ }^{62}$ limits the development of biologics in this area at this time.

Biologics have a discrete mechanism of action directed against defined pathological mechanisms. While this is a potential advantage of biologics, in terms of target specificity, over conventional treatments, the complexity of COPD means that specificity to one disease mechanism may limit effectiveness. The challenge is to develop biomarkers that would predict efficacy e.g., using blood eosinophils to predict 
responsiveness to anti-IL-5/anti-IL-5R $\alpha$ treatment for patients at increased risk of future exacerbations. Although there are conflicting data on whether blood eosinophils predict COPD clinical outcomes such as exacerbations ${ }^{26,33}$, there is accumulating evidence from retrospective and prospective studies that blood eosinophils can be used as a biomarker to predict inhaled corticosteroid effects ${ }^{63,64}$. The results of the anti-IL-5/IL-5R $\alpha$ clinical trials also indicate the potential for this biomarker to predict drug effects of biologic therapies that specifically target eosinophils.

Potential COPD targets for the development of novel biologic therapies include reduction in bacterial colonization, prevention of emphysema, and reduction of eosinophilic inflammation. Bacterial colonization leads to an amplified innate immune response. Disengaging the innate immune response and the microbiome is difficult, and a challenge for the development of biologics that aim to target innate immunity alone. The targeting of elastases, which are associated with the disruption of lung tissue, could potentially reduce progressive emphysema. However, this may be problematic because of the different protease mechanisms involved, meaning that targeting a single protease may be insufficient.

Some potential targets identified and being investigated for biologic therapy in COPD include C-type lectin receptor (CLEC5A), autoantibodies, and IL-33. CLEC5A is expressed on alveolar macrophages in mice exposed longterm to cigarette smoke and is required for the development of inflammation and proinflammatory cytokine expression ${ }^{65}$. The autoantibodies to anti-glucose-regulated protein 78 are associated with emphysema ${ }^{44}$. IL-33 is a type 2 cytokine that is upregulated by cigarette smoke, released in response to viral infection, and associated with driving $\mathrm{Th}_{1}$ celllike inflammatory response to viral infection ${ }^{65}$. Expression of IL-33 correlates with disease severity, and it is also thought to play a critical role in pathogen-induced exacerbations of COPD ${ }^{65}$. Therefore, blocking its activity has the potential to act on several aspects of COPD. Perhaps the most exciting aspect of this treatment is the potential to attenuate excessive inflammation during viral infections, which are known to be a key cause of more severe and prolonged exacerbations ${ }^{21}$.

Further characterization of the molecular pathology of COPD is likely to lead to identification of novel therapeutic targets. However, this approach needs to be married to the development of biomarkers to identify patients with abnormal expression of these mechanisms (endotypes). The future approach for biologic treatments must use clinical characteristics (e.g., risk of exacerbations) plus biomarkers to guide patient selection ${ }^{4}$. A potential barrier to the introduction of biologics for the treatment of patients with COPD includes access to treatment. Treatment with biologics will require patient management to change from being directed largely by primary care physicians to being guided by specialist respiratory physicians.

\section{CONCLUSIONS}

Historically, biologic therapies in COPD have been developed to target components of the innate immune response, such as CXCL8 and TNF. The failure of this strategy has led to an alternative approach in which monoclonal 
antibodies initially developed for asthma (anti-IL5/IL-5R $\alpha$ ) have been studied for COPD. However, these agents will be effective only in a subset of patients with COPD with eosinophilic inflammation. Biologic treatments in preclinical or early clinical development are currently focusing on mechanisms involved in exacerbations.

A key hurdle to the development of biologics in COPD is the difficulty of developing effective therapies targeting the innate immune system because of its complex relationship with the lung microbiome. Furthermore, the substantial burden of comorbidities in COPD patients can impede the ability of any one treatment to improve overall symptoms and health-related quality of life (HRQOL). Currently, the most promising biologic treatments at an advanced stage of development for COPD are agents targeting eosinophilia, either via anti-IL-5 or anti-IL-5R $\alpha$ mechanisms. However, these agents will only be effective in a subset of patients with COPD with eosinophilic inflammation. In recent years, there has been increased focus on targeting proteins involved in the immune response to viral infection, such as anti-IL-33. There are inherent risks in such an approach, such as susceptibility to severe infection. Although research over the next 5 years is likely to focus on anti-eosinophil treatment for COPD, we speculate that approaches to target exacerbation mechanisms such as anti-IL-33 treatment could also hold great potential. The development of biologics in COPD is unlikely to be a smooth path. However, the value of biologics is increased if we adopt a precision medicine approach focusing on endotypes, subjacent pathophysiology and concurrent development of biomarkers.

\section{CONFLICTS OF INTEREST}

Dr. Ubaldo Martin is an employee of AstraZeneca, the manufacturer of benralizumab. Dr. Dave Singh reports personal fees from Apellis, grants and personal fees from AstraZeneca, grants and personal fees from Boehringer Ingleheim, grants and personal fees from Chiesi, personal fees from Cipla, personal fees from Genentech, grants and personal fees from GlaxoSmithKline, grants and personal fees from Glenmark, grants and personal fees from Menarini, grants and personal fees from Merck, grants and personal fees from Mundipharma, grants and personal fees from Novartis, personal fees from Peptinnovate, grants and personal fees from Pfizer, grants and personal fees from Pulmatrix, personal fees from Skyepharma, grants and personal fees from Teva, grants and personal fees from Therevance, grants and personal fees from Verona, outside the submitted work.

\section{ACKNOWLEDGMENTS}

Writing and editing support, including preparation of the draft manuscript under the direction and guidance of the authors, incorporating author feedback, and manuscript submission, was provided by Debra Scates, PhD, of Endpoint Medical Communications (Conshohocken, PA, USA) and Michael A. Nissen, ELS, of AstraZeneca (Gaithersburg, MD, USA). This support was funded by AstraZeneca.

\section{REFERENCES}

1. Saetta M, Turato G, Zuin R. Structural basis for airflow limitation in chronic obstructive pulmonary disease. Sarcoidosis Vasc Diffuse Lung Dis. 2000;17:239-45. 
2. Singh D, Roche N, Halpin D et al. Current controversies in the pharmacological treatment of chronic obstructive pulmonary disease. Am J Respir Crit Care Med. 2016;194:541-9.

3. Agusti A, Gea J, Faner R. Biomarkers, the control panel and personalized COPD medicine. Respirology. 2016;21:24-33.

4. Agusti A, Bel E, Thomas M et al. Treatable traits: toward precision medicine of chronic airway diseases. Eur Respir J. 2016;47:410-19.

5. Bel EH, Ten Brinke A. New anti-eosinophil drugs for asthma and COPD: Targeting the trait! Chest. 2017.

6. Nixon J, Newbold P, Mustelin T et al. Monoclonal antibody therapy for the treatment of asthma and chronic obstructive pulmonary disease with eosinophilic inflammation. Pharmacol Ther. 2017;169:57-77.

7. Pavord ID, Beasley R, Agusti A et al. After asthma: redefining airways diseases. Lancet. 2017.

8. Schwab P, Dhamane AD, Hopson SD et al. Impact of comorbid conditions in COPD patients on health care resource utilization and costs in a predominantly Medicare population. Int J Chron Obstruct Pulmon Dis. 2017; 12:735-44.

9. Williams L, Wilcox D, ZuWallack R et al. Integrated Care: What does this mean for the COPD Patient? Chron Obstruct Pulmon Dis. 2016;1:18.

10. Vogelmeier CF, Criner GJ, Martinez FJ et al. Global strategy for the diagnosis, management and prevention of chronic obstructive lung disease 2017 report: GOLD executive summary. Respirology. 2017;22:575-601.

11. Caramori G, Casolari P, Barczyk A et al. COPD immunopathology. Semin Immunopathol. 2016;38:497-515.

12. Hogg JC, Timens W. The pathology of chronic obstructive pulmonary disease. Annu Rev Pathol. 2009;4:435-59.

13. van Eeden SF, Sin DD. Oxidative stress in chronic obstructive pulmonary disease: a lung and systemic process. Can Respir J. 2013;20:27-9.

14. Tzortzaki EG, Papi A, Neofytou E et al. Immune and genetic mechanisms in COPD: possible targets for therapeutic interventions. Curr Drug Targets. 2013;14:141-8.

15. Ponce-Gallegos MA, Ramirez-Venegas A, Falfan-Valencia R. Th17 profile in COPD exacerbations. Int J Chron Obstruct Pulmon Dis. 2017;12:1857-65.

16. Barnes PJ. New anti-inflammatory targets for chronic obstructive pulmonary disease. Nat Rev Drug Discov. 2013;12:543-59.

17. Hogg JC, Chu F, Utokaparch S et al. The nature of small-airway obstruction in chronic obstructive pulmonary disease. N Engl J Med. 2004;350:2645-53.

18. Caramori G, Casolari P, Giuffre S et al. COPD pathology in the small airways. Panminerva Med. 2011;53:51-70.

19. Saha S, Brightling CE. Eosinophilic airway inflammation in COPD. Int J Chron Obstruct Pulmon Dis. 2006;1:39-47.

20. GOLD. Global strategy for the diagnosis, management, and prevention of chronic obstructive pulmonary disease. 2017. Available at: http://goldcopd.org/about-us/ (accessed September 2017).

21. Lakshmi SP, Reddy AT, Reddy RC. Emerging pharmaceutical therapies for COPD. Int J Chron Obstruct Pulmon Dis. 2017;12:2141-56.

22. Bathoorn E, Liesker JJ, Postma DS et al. Change in inflammation in out-patient COPD patients from stable phase to a subsequent exacerbation. Int J Chron Obstruct Pulmon Dis. 2009;4:101-9.

23. Bafadhel M, McKenna S, Terry S et al. Acute exacerbations of chronic obstructive pulmonary disease: identification of biologic clusters and their biomarkers. Am J Respir Crit Care Med. 2011;184:662-71.

24. Papi A, Luppi F, Franco F et al. Pathophysiology of exacerbations of chronic obstructive pulmonary disease. Proc Am Thorac Soc. 2006;3:245-51.

25. Makris D, Lazarou S, Alexandrakis $\mathrm{M}$ et al. Tc2 response at the onset of COPD exacerbations. Chest. 2008;134:483-8.

26. Vedel-Krogh S, Nielsen SF, Lange P et al. Blood eosinophils and exacerbations in chronic obstructive pulmonary disease. The Copenhagen general population study. Am J Respir Crit Care Med. 2016;193:965-74.

27. Chung KF, Adcock IM. Multifaceted mechanisms in COPD: inflammation, immunity, and tissue repair and destruction. Eur Respir J. 2008;31:1334-56.

28. Caramori G, Adcock IM, Di Stefano A et al. Cytokine inhibition in the treatment of COPD. Int J Chron Obstruct Pulmon Dis. 2014;9:397-412.
29. Accortt NA, Chung JB, Bonafede M et al. Retrospective analysis to describe associations between tumor necrosis factor alpha inhibitors and COPD-related hospitalizations. Int J Chron Obstruct Pulmon Dis. 2017;12 2085-94.

30. Tripple JW, McCracken JL, Calhoun WJ. Biologic therapy in chronic obstructive pulmonary disease. Immunol Allergy Clin North Am. 2017;37: 345-55.

31. Russell DW, Wells JM, Blalock JE. Disease phenotyping in chronic obstruc tive pulmonary disease: the neutrophilic endotype. Curr Opin Pulm Med. 2016;22:91-9.

32. Kolsum U, Damera G, Pham TH et al. Pulmonary inflammation in patients with chronic obstructive pulmonary disease with higher blood eosinophil counts. J Allergy Clin Immunol. 2017.

33. Singh D, Kolsum U, Brightling CE et al. Eosinophilic inflammation in COPD: prevalence and clinical characteristics. Eur Respir J. 2014;44 1697-700.

34. Siva R, Green RH, Brightling CE et al. Eosinophilic airway inflammation and exacerbations of COPD: a randomised controlled trial. Eur Respir J. 2007;29:906-13.

35. Couillard S, Larivee P, Courteau J et al. Eosinophils in COPD Exacerbations are associated with increased readmissions. Chest. 2017;151:366-73.

36. Saetta M, Di Stefano A, Maestrelli P et al. Airway eosinophilia in chronic bronchitis during exacerbations. Am J Respir Crit Care Med. 1994;150 1646-52.

37. Kim SW, Rhee CK, Kim KU et al. Factors associated with plasma IL-33 levels in patients with chronic obstructive pulmonary disease. Int J Chron Obstruct Pulmon Dis. 2017;12:395-402.

38. Sze MA, Hogg JC, Sin DD. Bacterial microbiome of lungs in COPD. Int Chron Obstruct Pulmon Dis. 2014;9:229-38.

39. Kolsum U, Donaldson GC, Singh R et al. Blood and sputum eosinophils in COPD; relationship with bacterial load. Respir Res. 2017;18:88.

40. Roos AB, Stampfli MR. Targeting Interleukin-17 signalling in cigarette smoke-induced lung disease: Mechanistic concepts and therapeutic opportunities. Pharmacol Ther. 2017;178:123-31.

41. Saetta M, Turato G, Maestrelli P et al. Cellular and structural bases of chronic obstructive pulmonary disease. Am J Respir Crit Care Med. 2001; 163:1304-9.

42. Ruan W, Wu M, Shi L et al. Serum levels of IGFBP7 are elevated during acute exacerbation in COPD patients. Int J Chron Obstruct Pulmon Dis. 2017;12:1775-80.

43. Yonchuk JG, Silverman EK, Bowler RP et al. Circulating soluble receptor for advanced glycation end products (sRAGE) as a biomarker of emphysema and the RAGE axis in the lung. Am J Respir Crit Care Med. 2015;192:785-92.

44. Bon J, Kahloon R, Zhang Y et al. Autoreactivity to glucose regulated protein 78 links emphysema and osteoporosis in smokers. PLoS One. 2014;9:e105066.

45. Rogliani P, Calzetta L, Ora J et al. Canakinumab for the treatment of chronic obstructive pulmonary disease. Pulm Pharmacol Ther. 2015;31:15-27.

46. Calverley PMA, Sethi S, Dawson M et al. A randomised, placebo-controlled trial of anti-interleukin-1 receptor 1 monoclonal antibody MEDI8968 in chronic obstructive pulmonary disease. Respir Res. 2017;18:153.

47. GSK. Nucala prescribing information. Available at: https://www.accessdata.fda.gov/drugsatfda_docs/label/2015/125526Orig1s000Lbl.pd (accessed September 2017).

48. Powell C, Milan SJ, Dwan K et al. Mepolizumab versus placebo for asthma Cochrane Database Syst Rev. 2015:Cd010834.

49. Pavord ID, Chanez P, Criner GJ et al. Mepolizumab for Eosinophilic Chronic Obstructive Pulmonary Disease. N Engl J Med. 2017;377:1613-29.

50. Kolbeck R, Kozhich A, Koike M et al. MEDI-563, a humanized anti-IL-5 receptor alpha $\mathrm{mAb}$ with enhanced antibody-dependent cell-mediated cytotoxicity function. J Allergy Clin Immunol. 2010;125:1344-53.

51. FitzGerald JM, Bleecker ER, Nair P et al. Benralizumab, an anti-interleukin-5 receptor alpha monoclonal antibody, as add-on treatment for patients with severe, uncontrolled, eosinophilic asthma (CALIMA): a randomised, double-blind, placebo-controlled phase 3 trial. Lancet. 2016;388:2128-41. 
52. Bleecker ER, FitzGerald JM, Chanez P et al. Efficacy and safety of benralizum$\mathrm{ab}$ for patients with severe asthma uncontrolled with high-dosage inhaled corticosteroids and long-acting beta2-agonists (SIROCCO): a randomised, multicentre, placebo-controlled phase 3 trial. Lancet. 2016;388:2115-27.

53. Brightling CE, Bleecker ER, Panettieri RA, Jr. et al. Benralizumab for chronic obstructive pulmonary disease and sputum eosinophilia: a randomised, double-blind, placebo-controlled, phase 2a study. Lancet Respir Med. 2014; 2:891-901.

54. Mahler DA, Huang S, Tabrizi M et al. Efficacy and safety of a monoclonal antibody recognizing interleukin-8 in COPD: a pilot study. Chest. 2004; 126:926-34.

55. Eich A, Urban V, Jutel M et al. A randomized, placebo-controlled phase 2 trial of CNTO 6785 in chronic obstructive pulmonary disease. COPD. 2017; 14:476-83.

56. Barnes PJ. Unexpected failure of anti-tumor necrosis factor therapy in chronic obstructive pulmonary disease. Am J Respir Crit Care Med. 2007; 175:866-7.

57. van der Vaart H, Koeter GH, Postma DS et al. First study of infliximab treatment in patients with chronic obstructive pulmonary disease. Am J Respir Crit Care Med. 2005;172:465-9.

58. Rennard SI, Fogarty C, Kelsen S et al. The safety and efficacy of infliximab in moderate to severe chronic obstructive pulmonary disease. Am J Respir Crit Care Med. 2007;175:926-34.

59. Suissa S, Ernst P, Hudson M. TNF-alpha antagonists and the prevention of hospitalisation for chronic obstructive pulmonary disease. Pulm Pharmacol Ther. 2008;21:234-8.

60. Aaron SD, Vandemheen KL, Maltais F et al. TNFalpha antagonists for acute exacerbations of COPD: a randomised double-blind controlled trial. Thorax. 2013;68:142-8.
61. Woodruff PG, Agusti A, Roche N et al. Current concepts in targeting chronic obstructive pulmonary disease pharmacotherapy: making progress towards personalised management. Lancet. 2015;385:1789-98.

62. Nussbaumer-Ochsner Y, Rabe KF. Systemic manifestations of COPD. Chest. 2011;1:165-73.

63. Pascoe S, Locantore N, Dransfield MT, Barnes NC, Pavord ID. Blood eosinophil counts, exacerbations, and response to the addition of inhaled fluticasone furoate to vilanterol in patients with chronic obstructive pulmonary disease: a secondary analysis of data from two parallel randomised controlled trials. Lancet Respir Med. 2015;3:435-42.

64. Siddiqui SH, Guasconi A, Vestbo J et al. Blood Eosinophils: A Biomarker of Response to Extrafine Beclomethasone/Formoterol in Chronic Obstructive Pulmonary Disease. Am J Respir Crit Care Med. 2015;192:523-5.

65. Kearley J, Silver JS, Sanden C et al. Cigarette smoke silences innate lymphoid cell function and facilitates an exacerbated type I interleukin-33-dependent response to infection. Immunity. 2015;42:566-79.

66. Bafadhel M, Greening NJ, Harvey-Dunstan TC et al. Blood Eosinophils and Outcomes in Severe Hospitalized Exacerbations of COPD. Chest. 2016;150: $320-8$.

67. Miyake K, Karasuyama H. Emerging roles of basophils in allergic inflammation. Allergol Int. 2017;66:382-91.

68. Fujii U, Miyahara N, Taniguchi A et al. IL-23 Is Essential for the Development of Elastase-Induced Pulmonary Inflammation and Emphysema. Am J Respir Cell Mol Biol. 2016;55:697-707.

69. Asquith KL, Ramshaw HS, Hansbro PM et al. The IL-3/IL-5/GM-CSF common receptor plays a pivotal role in the regulation of Th2 immunity and allergic airway inflammation. J Immunol. 2008;180:1199-206. 